\title{
Growth Hormone mRNA in Mammary Gland Tumors of Dogs and Cats
}

Jan A. Mol, Evert van Garderen, * Paulus J. Selman, Jeannette Wolfswinkel, Ad Rijnberk, and Gerard R. Rutteman Department of Clinical Sciences of Companion Animals, and *Department of Pathology, Faculty of Veterinary Medicine, Utrecht University, The Netherlands

\begin{abstract}
We have shown recently that in the dog progestin administration results in mammary production of immunoreactive growth hormone (GH). At present we demonstrate the expression of the gene encoding GH in the mammary gland of dogs and cats using reverse-transcriptase PCR.

GH mRNA was found in the great majority of normal mammary tissues as well as benign and malignant mammary tumors of the dog and was associated with the presence of immunoreactive GH in cryostat sections. The mammary PCR product proved to be identical to that of the pituitary. The highest expression levels were found after prolonged treatment with progestins. In carcinomas GH mRNA was also found in progesterone receptor-negative tissue samples, indicating that after malignant transformation GH gene expression may become progestin independent. GH mRNA was also present in mammary tissues of cats with progestin-induced fibroadenomatous changes.

It is concluded that GH gene expression occurs in normal, hyperplastic, and neoplastic mammary tissue of the dog. The expression in normal tissue is stimulated by progestins and might mediate the progestin-stimulated development of canine mammary tumors. The demonstration of progestin-stimulated GH expression in mammary tissue of cats indicates that the phenomenon is more generalized among mammals. (J. Clin. Invest. 1995. 95:2028-2034.) Key words: cats • dogs • mammary tumor • progestins • growth hormone
\end{abstract}

\section{Introduction}

The role of progestins in the pathogenesis of human breast cancer has been highly debated (1-4). Although there is convincing evidence that ovarian hormones play a prominent role at all stages of mammary development, epidemiologic studies in general do not support an overall increased risk of breast cancer after progestin treatment. However, oral contraceptives or depot medroxyprogesterone acetate does not decrease the risk of female breast cancer, in contrast to inhibitory effect on the risk of developing endometrial cancer. Furthermore, several epidemiologic studies have linked the use of contraceptive agents during adolescence or before a full-term pregnancy to a

Address correspondence to Dr. Ir. J. A. Mol, Department of Clinical Sciences of Companion Animals, Utrecht University, P. O. Box 80.154, 3508 TD Utrecht, The Netherlands. Phone: 313-053-1709; FAX: 313051-8126.

Received for publication 31 August 1994 and in revised form 30 December 1994.

J. Clin. Invest.

(c) The American Society for Clinical Investigation, Inc.

0021-9738/95/05/2028/07 \$2.00

Volume 95, May 1995, 2028-2034 higher risk of developing breast cancer at a young age (4-6). The question of whether this increased risk is attributable to the estrogen or the progestin content of the contraceptives has not been answered satisfactorily, but there is good reason to think that this increased risk may be due to the progestin component (7-9). This hypothesis is supported by the observations that the highest proliferation rates of mammary epithelium are found in the progesterone-dominated luteal phase of the menstrual cycle and in women receiving progestin-only formulations of contraceptives $(3,10)$, indicating a strong mitogenic action of progestins upon mammary epithelium.

In dogs and cats, as in humans, spontaneous forms of benign and malignant mammary gland tumors are found. These animals may therefore provide a model, in addition to the carcinogeninduced mammary tumors in rodents, for the study of comparative aspects of mammary tumor formation. In the dog many toxicity studies have been carried out with estrogens and progestins. Prolonged administration of estrogens does not increase the incidence of mammary tumors in the dog (11), but treatment of female dogs with progestins causes mammary tumor development in a dose-dependent manner (11-15). Many of the neoplastic changes are benign, but malignant tumors have also been encountered $(14,15)$.

Some 14 yr ago it was shown that exogenous (16-18) and endogenous (19) progestins may induce a syndrome of growth hormone $(\mathrm{GH})^{1}$ excess in the dog, leading to acromegalic features and glucose intolerance. The GH excess is reversible upon progestin withdrawal. Very recently we reported that this progestin-induced growth hormone excess originates from foci of hyperplastic ductular epithelium of the mammary gland (20).

In cats progestins also induce mammary hyperplasia, sometimes resulting in extensive fibroadenomatous changes (21). This proliferation of mammary duct epithelium and stroma occurs in the luteal phase of the estrous cycle, in the early stages of pregnancy, and after administration of progestins (22). In cats, however, administration of progestins does not result in increased circulating concentrations of GH (23).

In this study we investigated the sequence of the cDNA encoding mammary GH in the dog and compared this sequence with the cDNA encoding pituitary GH. The presence of the GH mRNA was investigated in normal mammary tissue and in benign and malignant mammary tumors of the dog. The presence of GH mRNA was also investigated in cats with fibroadenomatous changes and other proliferative lesions in the mammary gland.

\section{Methods}

Origin of mammary tissue. Eight mammary tissue samples were obtained from female experimental beagle dogs that had been treated with long-acting progestins after ovariohysterectomy. Full details of treat-

1. Abbreviations used in this paper: $\mathrm{ER}$, estrogen receptor; $\mathrm{GH}$, growth hormone; MPA, medroxyprogesterone acetate; PR, progestin receptor; $\mathrm{RT}$, reverse transcriptase. 

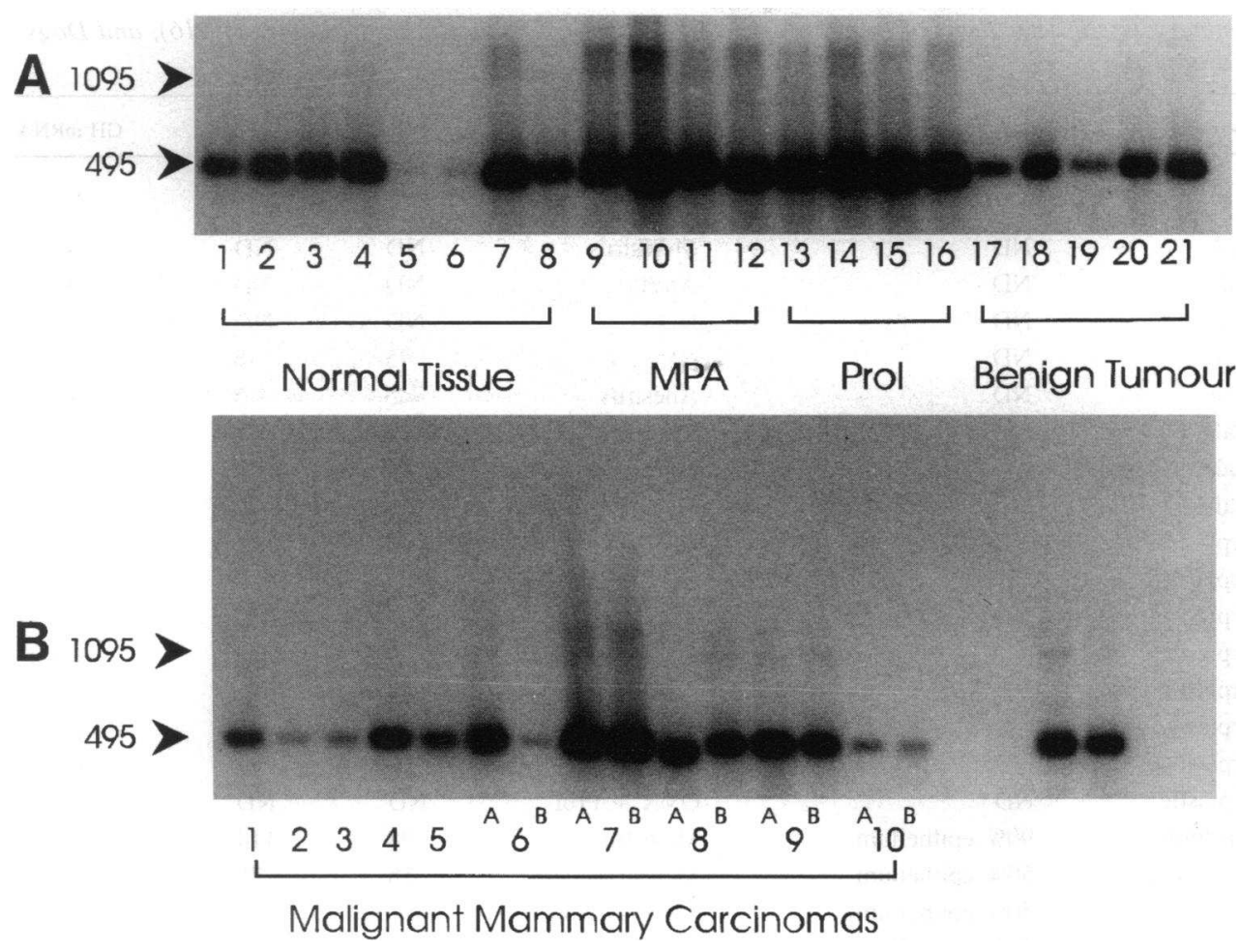

Figure 1. Size separation by electrophoresis on $1.5 \%$ agarose of the RT-PCR products obtained from $1 \mu \mathrm{g}$ total RNA of canine mammary tissues using porcine specific GH primers. The RT-PCR products were hybridized after a Southern blot using a ${ }^{32} \mathrm{P}$-labeled canine GH cDNA probe. The codes for the products correspond to the data for the tissue samples in Table I. $(A)$ Samples 1-8 were obtained from female dogs at various stages of the reproductive cycle. Samples 9-16 were obtained after pretreatment with the synthetic progestins MPA or proligeston (Prol). Samples 17-21 were classified as benign mammary tumors. (B) Samples derived from malignant tumors. ment and hormonal changes have been published previously (20). Briefly, four dogs were treated with medroxyprogesterone acetate (MPA; Upjohn, Ede, The Netherlands; $10 \mathrm{mg} / \mathrm{kg}$ body wt), and four dogs were treated with proligestone (Mycofarm, De Bilt, The Netherlands; $50 \mathrm{mg} / \mathrm{kg}$ body wt). The progestins were administered at 3-wk intervals for a total of 8 injections, stopped for $6 \mathrm{mo}$, and then resumed at the same doses and intervals for a total of 5 additional injections. Mammary glands were collected immediately after excision, frozen in liquid nitrogen, and stored at $-70^{\circ} \mathrm{C}$ until analysis. The other mammary specimens were obtained in the same manner from privately owned dogs and cats that were referred to the Utrecht University Clinic for Companion Animals. Mammary tumors and unaffected mammary tissue were well separated from each other during collection at surgery or, in inoperable cases, at autopsy. Sections from all macroscopically tumorous and nontumorous specimens were processed for routine histopathology and classified as described (24).

Reverse transcriptase polymerase chain reaction (RT-PCR). Total RNA was isolated using the guanidinium isothiocyanate (GITC) method. Briefly, $1 \mathrm{~g}$ of tissue was homogenized in $10 \mathrm{ml}$ denaturing mix (4 M GITC, $25 \mathrm{mM}$ sodium citrate, $0.5 \%$ [wt/vol] sarcosyl, and $1 \% \beta$-mercaptoethanol) by ultra-turrax (Janke \& Kunkel, Staufen, Germany) for $30 \mathrm{~s}$. To the homogenate was added $1 \mathrm{ml} 2 \mathrm{M} \mathrm{NaOAc}(\mathrm{pH}$ 4.5), $10 \mathrm{ml}$ phenol, and $2 \mathrm{ml}$ chloroform:iso-amylalcohol (24:1), and this was followed by incubation on ice for $15 \mathrm{~min}$. From the upper phase, obtained after centrifugation for $15 \mathrm{~min}$ at $10,000 \mathrm{~g}$, total RNA was precipitated with $10 \mathrm{ml}$ isopropanol by incubation for $1 \mathrm{~h}$ at $-70^{\circ} \mathrm{C}$ and centrifugation at $3,600 \mathrm{~g}$. The pellet was redissolved in denaturing mix and RNA was again precipitated by isopropanol. After washing with 75\% ethanol the RNA pellet was dried under vacuum and redissolved in $10 \mathrm{mM}$ Tris ( $\mathrm{pH} 8.0$ ) containing $1 \mathrm{mM}$ EDTA.

The RNA samples were analyzed by RT-PCR amplification. For the RTs, $1 \mu \mathrm{g}$ total RNA was added to a $20 \mu \mathrm{l}$ (final volume) reaction containing $1 \times$ AMV buffer (Promega Corp., Madison, WI), $5 \mathrm{mM}$ $\mathrm{MgCl}_{2}, 1 \mathrm{mM}$ of each deoxynucleotide triphosphate, $20 \mathrm{U}$ RNase inhibitor (RNasin; Promega Corp.), 12 U AMV reverse transcriptase, and 2.5 $\mu \mathrm{M}$ Oligo $\mathrm{d}(\mathrm{T})_{15}$ primer. The reaction mixture was overlaid with $50 \mu \mathrm{l}$ of mineral oil and incubated at $42^{\circ} \mathrm{C}$ for $60 \mathrm{~min}$, followed by heat denaturation at $99^{\circ} \mathrm{C}$ for $5 \mathrm{~min}$ and cooling at $5^{\circ} \mathrm{C}$ for $5 \mathrm{~min}$. The total RT reaction was then subjected to PCR amplification using cDNA primers derived from the sequence of the porcine GH gene from the second to the fifth exon (upstream primer: $5^{\prime}$-TTCCCAGCCATGCCCTTGTCC; downstream primer: 5'-CTTGAAGCAGGAGAGCAGCCC). The upstream primer coincides with the start codon of the $\mathrm{GH}$ sequence, which is $60 \mathrm{bp}$ downstream from the start codon of the preprohormone starting with a signal peptide. The downstream primer ends within the coding sequence of the fifth exon. To the RT mixture was added $69.5 \mu \mathrm{l}$ sterile bidistilled water, $0.5 \mu \mathrm{l}$ Ampli Taq DNA polymerase ( $5 \mathrm{U} / \mu \mathrm{l}$; Promega Corp.), $8 \mu \mathrm{l} 10 \times \mathrm{Taq}$ buffer, and $1 \mu \mathrm{l}$ of each primer $(10 \mathrm{pmol})$. After an initial denaturation for $5 \mathrm{~min}$ at $95^{\circ} \mathrm{C}$ the cDNA was amplified by 35 cycles of $1 \mathrm{~min}$ at $95^{\circ} \mathrm{C}, 1 \mathrm{~min}$ at $55^{\circ} \mathrm{C}$, and $1 \mathrm{~min}$ at $72^{\circ} \mathrm{C}$. Samples were kept for $10 \mathrm{~min}$ at $72^{\circ} \mathrm{C}$ after the last amplification cycle.

$10 \%$ of the PCR product was size-fractionated by electrophoresis on a $1.5 \%$ agarose gel, stained with ethidium bromide, and photographed under ultraviolet light. The PCR products were then transferred by southern blotting to Hybond- $\mathrm{N}^{+}$nitrocellulose membranes (Amersham International, Buckinghamshire, United Kingdom) and hybridized with a ${ }^{32} \mathrm{P}$-random-labeled canine $\mathrm{GH}$ probe purified for sequence analysis.

In an additional study a semi-quantitative RT-PCR was performed for the analysis of the progestin induction of mammary GH mRNA expression. Therefore the RT-PCR of GH mRNA was performed in the presence of primers directed against the mRNA encoding the housekeeping gene $\beta$-actin (upstream primer: 5'-GGCTGGGGTGTTGAAGGTCTC; downstream primer: 5'-GATATCGCCGCGCTCGTCGTC).

Sequence analysis. The 495-bp fragment obtained from mammary tissue of experimental dogs treated with progestins was isolated from the gel and subjected to a second PCR amplification. The sequence of this product was determined by the dideoxy method (25). The 600-bp fragment found in mammary tumor tissue of dogs was also subjected to a second PCR amplification and partially sequenced. The sequences were analyzed with the $P C / G E N E$ software package (IntelliGenetics, Inc./Betagen, Mountain View, CA). Homology comparisons were made with the EMBL sequence database of the CAOS/CAMM Centre (Nijmegen, The Netherlands).

Immunohistochemistry. The presence of GH in mammary tissue was shown by immunohistochemical analysis of 5- $\mu \mathrm{m}$ sections of frozen specimens of canine mammary tumors as described previously (20). A rabbit anti-porcine GH antiserum was used as the primary antibody. 
Table I. Some Characteristics of Mammary Tissue Specimens of Healthy Control Dogs (1-8), Progestin-treated Dogs (9-16), and Dogs with Benign (17-21) or Malignant Tumors

\begin{tabular}{|c|c|c|c|c|c|c|c|}
\hline Sample & Code & Histology & $\%$ Cells & Cycle & ER & PR & GH mRNA \\
\hline \multicolumn{8}{|c|}{ Normal and hyperplastic tissues } \\
\hline 1 & A7 & Normal & ND & Metestrus & ND & ND & + \\
\hline 2 & A11 & Normal & ND & Anestrus & ND & ND & + \\
\hline 3 & P206B & Normal & ND & ND & ND & ND & + \\
\hline 4 & Et44B & Normal & ND & ND & 45 & 78 & + \\
\hline 5 & Et42 & Inactive & ND & Anestrus & $<5$ & $<5$ & - \\
\hline 6 & 8609 & Normal & ND & Anestrus & 19 & 18 & - \\
\hline 7 & P117R4 & Normal & ND & Metestrus & ND & ND & ++ \\
\hline 8 & P182L4 & Normal & ND & MPA -5 mo & 35 & 36 & + \\
\hline 9 & $\mathrm{~A} 2$ & Hyperplastic & ND & OVX + MPA & ND & ND & ++ \\
\hline 10 & $\mathrm{~A} 3$ & Hyperplastic & ND & OVX + MPA & ND & ND & ++ \\
\hline 11 & A4 & Hyperplastic & ND & OVX + MPA & ND & ND & ++ \\
\hline 12 & A5 & Hyperplastic & ND & OVX + MPA & ND & ND & ++ \\
\hline 13 & B1 & Hyperplastic & ND & OVX + Prol & ND & ND & ++ \\
\hline 14 & B4 & Hyperplastic & ND & OVX + Prol & ND & ND & ++ \\
\hline 15 & B6 & Hyperplastic & ND & OVX + Prol & ND & ND & ++ \\
\hline 16 & B7 & Hyperplastic & ND & OVX + Prol & ND & ND & ++ \\
\hline 17 & P154 & Benign tumor & $90 \%$ epithelium & Metestrus & 98 & 114 & + \\
\hline 18 & P79 & Benign tumor & $50 \%$ epithelium & Metestrus & 58 & 75 & + \\
\hline 19 & P51L4 & Benign tumor & $50 \%$ epithelium & MPA -3 mo & 22 & $<5$ & $+1-$ \\
\hline 20 & P81R4 & Benign tumor & $50 \%$ epithelium & MPA -4 mo & 25 & 45 & + \\
\hline 21 & $\mathrm{P} 60$ & Benign tumor & $50 \%$ epithelium & Metestrus & 96 & 173 & + \\
\hline
\end{tabular}

Malignant mammary carcinomas

\begin{tabular}{|c|c|c|c|c|c|c|c|}
\hline 1 & P78 & Anaplastic & $30 \%$ carcinoma & Metestrus & 18 & 21 & + \\
\hline 2 & P157 & Tubular & $40 \%$ carcinoma & OVX -2 yr & $<5$ & 26 & $+1-$ \\
\hline 3 & P159 & Anaplastic & $5 \%$ carcinoma & Prol -7 mo & ND & ND & $+1-$ \\
\hline 4 & P177 & Solid & $75 \%$ carcinoma & $\mathrm{OVX}-3 \mathrm{yr}$ & 6 & $<5$ & + \\
\hline 5 & P191R4 & Solid & $40 \%$ carcinoma & OVX -5 yr & 3 & $<5$ & + \\
\hline $6 \mathrm{~A}$ & P170R5 & Complex & $90 \%$ carcinoma & Metestrus & 42 & 147 & + \\
\hline $6 B$ & P170L4 & Normal 6A & $70 \%$ epithelium & Metestrus & 119 & 40 & $+1-$ \\
\hline $7 \mathrm{~A}$ & P221L4 & Anaplastic & $5-70 \%$ carcinoma & Prol-1 wk & ND & ND & ++ \\
\hline $7 \mathrm{~B}$ & P221L5 & Normal 7A & ND & Prol-1 wk & ND & ND & ++ \\
\hline $8 \mathrm{~A}$ & $\mathrm{P} 1881$ & Carcinoma & $1 \%$ carcinoma & Lactating & ND & ND & + \\
\hline $8 B$ & P188ln & Metastasis & $40 \%$ carcinoma & Lactating & ND & ND & + \\
\hline $9 \mathrm{~A}$ & P211L3 & Carcinoma & $70 \%$ carcinoma & $\mathrm{MPA}-2 \mathrm{mo}$ & ND & ND & + \\
\hline 9B & P211ln & Metastasis & $90 \%$ carcinoma & MPA -2 mo & ND & ND & + \\
\hline $10 \mathrm{~A}$ & P217R4 & Carcinoma & $25-50 \%$ carcinoma & Lactating & 4 & 12 & $+1-$ \\
\hline $10 \mathrm{~B}$ & P217ln & Metastasis & $50 \%$ carcinoma & Lactating & 2 & $<3$ & $+1-$ \\
\hline
\end{tabular}

Samples correspond to the numbers of Fig. 1. Histology, findings in formaldehyde-fixed tissue samples. Cycle, OVX, ovariohysterectomy; the time is the interval between intervention and tissue sampling; Prol, proligeston. ER/PR, receptor concentrations in fmol/mg protein in tissue cytosol. ND, not done. GH mRNA, ++, abundant; +, present; -, absent; +l-, faint band.

The antiserum was a generous gift of Dr. M. M. Bevers (Department of Herd Health and Reproduction, Faculty of Veterinary Medicine, Utrecht University). A peroxidase-conjugated, goat anti-rabbit IgG antiserum was used as the second antibody. Specimens in which the first antiserum was omitted served as negative controls.

Steroid receptor analysis. Determination of estrogen (ER) and progestin receptors (PR) in frozen tissue specimens was performed by a multiconcentration dextran-coated charcoal assay (26).

\section{Results}

All experimental dogs treated with high doses of either MPA or proligestone had developed acromegalic features (20). Am- plification of GH mRNA in nontumorous mammary tissue samples of these dogs by RT-PCR using porcine specific GH primers resulted in the presence of a 495-bp fragment in all samples (Fig. $1 A$; Table I). Single strand conformation polymorphism analysis revealed no difference between the 495-bp products obtained from the pituitary and mammary tissue (not shown). The identity of the mammary and the pituitary products was confirmed by sequence analysis (Fig. 2). A very high homology was found with pituitary GH sequences of other species. The highest homology was found with mink and porcine GH, and lower homology was found with GH from artiodactyls and from rat and various human GH variant genes (Fig. 3). 


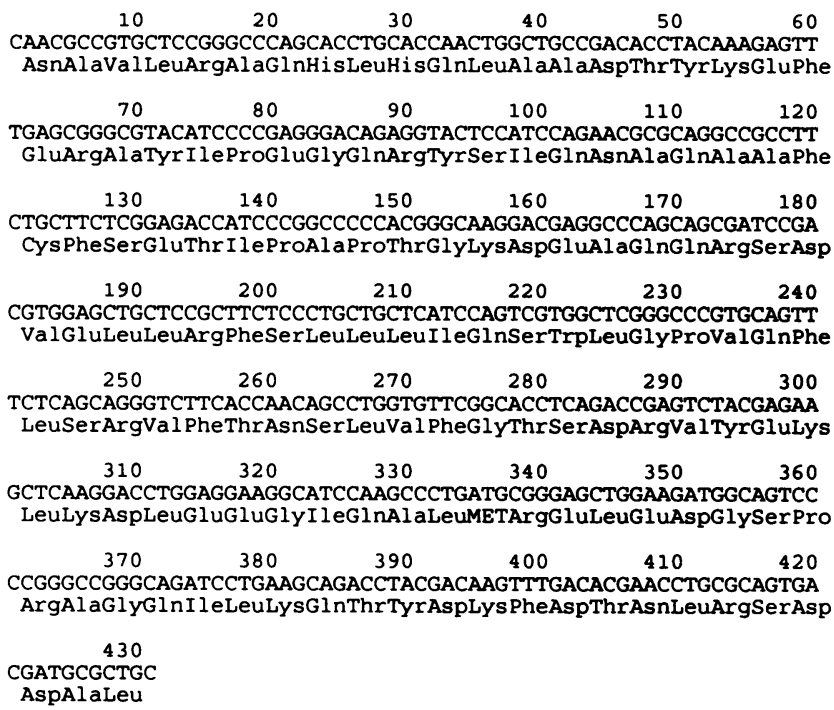

Figure 2. Nucleotide sequence of the 495-bp fragment amplified by RTPCR from canine mammary gland RNA using porcine specific GH primers and the translation into protein. The product proved to be identical to the 495-bp fragment obtained by amplification of pituitary GH mRNA.

GH mRNA was expressed in most of the normal, benign, and malignant mammary tissues of dogs, listed in Table I (Fig. 1). The presence of GH mRNA corresponded to the immunohistochemical staining of tissue specimens with anti-porcine $\mathrm{GH}$ antiserum (Fig. 4). The GH immunoreactivity was predominantly localized in cells of hyperplastic ductular epithelium. Although the RT-PCR is not quantitative, the highest concentrations of the 495-bp fragment were obtained after amplification of cDNA of dogs treated with progestins. GH mRNA was absent in one sample of inactive tissue that was PR negative and in one tissue sample obtained from a dog in anestrus (Table I). Among the five benign tumors, the lowest amount of GH mRNA was found in a PR-negative tissue sample.

There was a large variation of $\mathrm{GH}$ mRNA concentrations in the malignant mammary carcinomas (Fig. $1 B$ ). The highest levels were found in dogs that had received progestins recently. The expression in primary tumor tissue was higher (Fig. $1 B$, sample 6 ) or comparable (Fig. $1 B$, sample 7) to that in normal tissue or metastases (Fig. $1 \mathrm{~B}$, samples $8-10$ ) obtained from the same dog. It is noteworthy that GH mRNA expression was found in PR-negative tissue of two solid tumors of dogs that had been ovariohysterectomized at least 3 yr before.

In female cats the highest expression of the 495-bp fragment was found in areas of fibroadenomatous changes induced by the administration of different progestins with or without estradiol (Table II, Fig. 5). The expression was also present in mammary tissue of a male cat that had been treated with the synthetic progestin delmadinone acetate (Fig. 5, sample 4), for its androgen antagonistic properties. No expression was found in two cases of feline epitheliosis. Varying amounts of the 495-bp fragment were present in mammary tissue of cats with mammary carcinomas. The expression was most prominent in a cat receiving megestrol acetate continuously.

For a more quantitative analysis of the GH mRNA expression, the RT-PCR reaction was performed in the presence of primers against GH mRNA and the housekeeping gene $\beta$-actin (Fig. 6). Ethidium bromide staining of the agarose gels on

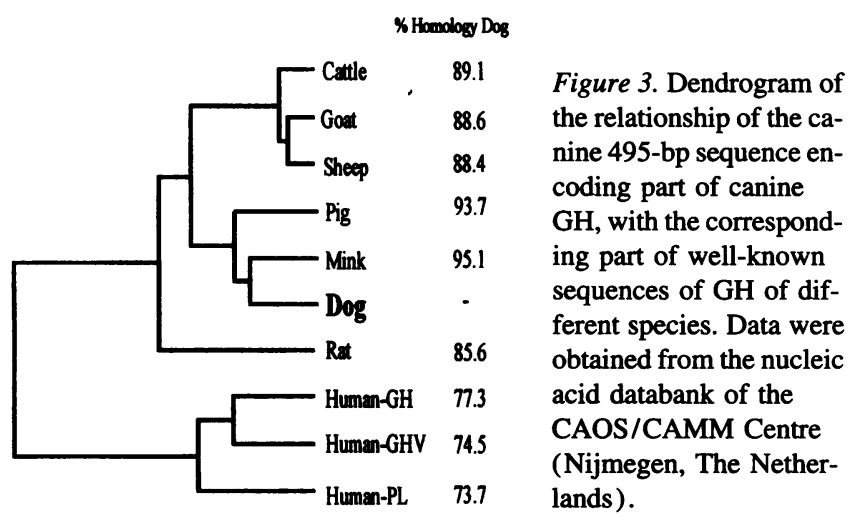

which the combined PCR products of canine mammary RNA were separated shows an enhanced concentration of the 495-bp GH mRNA product in comparison with the concentration of the 383-bp product of $\beta$-actin after progestin treatment (Fig. 6). As shown, a 600-bp fragment is amplified in the RT-PCR. In other tissue samples, whether normal, hyperplastic, or neoplastic, a 600-bp fragment was also amplified. This fragment did not react with the canine GH probe on the Southern blot, indicating that this fragment was not related to the GH mRNA. Sequence analysis of the 600 -bp fragment failed to demonstrate an unambiguous homology to well-known genes of other species. Translation of the $5^{\prime}$ side of the PCR product, using an open reading frame, showed motifs in the corresponding protein sequence of a glycosaminoglycan attachment site and an RGD structure pointing to a cell attachment sequence (Fig. 7).

\section{Discussion}

The demonstration of the expression of the gene encoding pituitary GH in canine and feline mammary tumors reveals a new aspect of the local endocrine environment of normal and tumorous mammary epithelium.

In the past decade, investigation of mechanisms involved in the growth regulation of breast cancer has changed from the concept of systemic endocrine stimulation of proliferation towards autocrine and paracrine processes. In the growth regulation of breast cancer cells, peptidergic growth factors play a prominent role. cDNA probes have revealed the expression of TGF $\alpha$, IGF-II, and PDGF in breast cancer epithelial cells (27). In research on endocrine stimulation of breast cancer the main attention has been focused on estrogens and prolactin, which are also produced in the mammary gland $(28,29)$. It has been shown that in human breast cancer there is autonomous regulation of the tissue estradiol concentration (29), which does not depend on plasma levels. The primary role of estrogens may be mainly related to induction of the PR concentration (10). In the dog, prolonged treatment with estrogens does not increase the incidence of mammary tumors (11) and is also not a prerequisite for the induction of $\mathrm{GH}$ excess by progestins $(18,20)$. In our limited series of feline fibroadenomatous lesions, expression of GH mRNA was found in animals treated with progestins and appeared not to depend on treatment with estrogens. GH mRNA expression was even present in a male cat treated with a synthetic progestin.

Of the pituitary hormones both nonlactogenic and lactogenic forms of GH have been proved to be far more potent than prolactin in directly stimulating mammary gland differentiation 

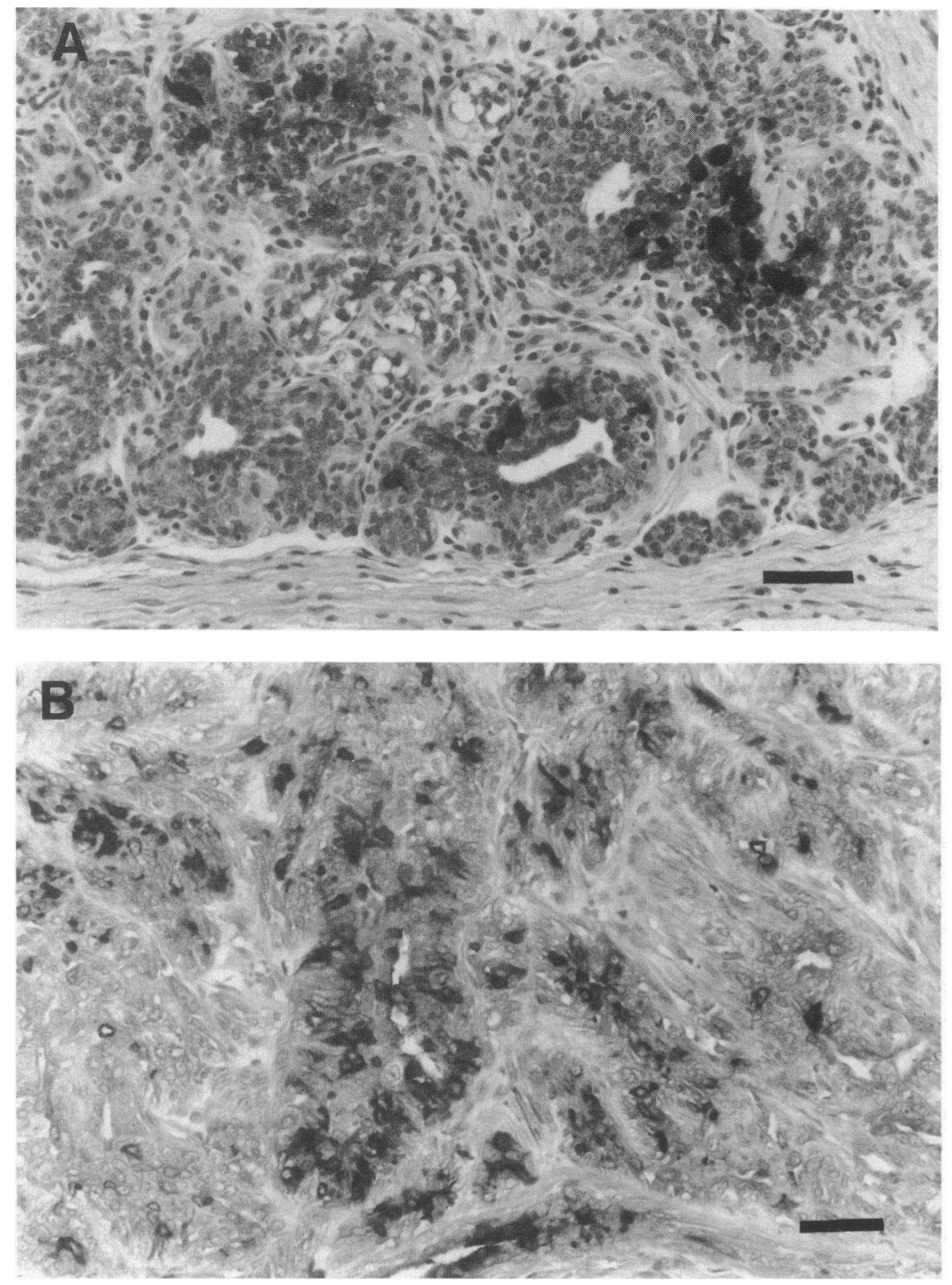

Figure 4. Immunochemical analysis of GH in canine mammary tissue on 5- $\mu \mathrm{m}$ slides obtained from paraffin-embedded, Bouin Hollande-fixated tissue specimen. $(A)$ Mammary tissue obtained after prolonged treatment of ovariohysterectomized dogs with synthetic progestins. The immunoreactive $\mathrm{GH}$ is present in epithelial cells in areas of hyperplastic ductular epithelium. Positive cells are situated in a basal to intermediate position in these hyperplastic areas. The bar represents $15 \mu \mathrm{m}$. $(B)$ Immunohistochemical staining for canine $\mathrm{GH}$ in a fibroadenoma, complex type. Immunoreactive cells are confined to tumorous secretory epithelium, myoepithelial proliferations are negative for $\mathbf{G H}$. The bar represents $15 \mu \mathrm{m}$.
(30). This important regulator of cell growth and differentiation has now been proved to be produced locally in the mammary gland of the dog and the cat under the influence of progestins. Mammary GH may have a physiological role in mammary gland differentiation. This differentiation requires recruitment of stem cells that, after an early differentiation, may fully develop into ductular epithelium by clonal expansion under the influence of the IGFs. This process may be a generalized dual effector pathway of the action of GH and IGFs in various tissues, as hypothesized by Green et al. (31). Malignant transformation may occur during the recruitment phase, giving rise to mammary cancer originating from mammary stem cells in both humans (32) and dogs (33). Moreover, progestins may enhance the mammary production of IGF-II, as shown in the human breast cancer cell line T-47D (34). Taken together, the progestin-induced synthesis and release of GH and of IGF-II may generate an environment highly promoting proliferation of the mammary epithelium. In humans, administration of high doses of MPA increases plasma IGF-I levels (35), most probably via increased plasma GH levels. Whether this is caused by local mammary $\mathrm{GH}$ production needs to be clarified. In view of the finding of progestin-induced GH expression in the mammary gland and the well-known tumor-promoting effect of progestins in dogs and cats (11), additional studies are needed to determine whether the tumorigenic effect of the steroid hormones is mediated by GH and GH-stimulated growth factors.

Progestins may temporarily enhance sensitivity to carcinogens by creating a highly proliferative environment. It is uncertain whether GH induction in the mammary gland is involved in this proliferative effect and contributes to tumorigenesis, or whether instead the local GH effects promote differentiation of the gland and are thus protective against initiation of tumor development.

In the benign mammary tumors of dogs and cats, a definite relationship was found between the presence of GH mRNA and exposure to endogenous or exogenous progestins. Such a 
Table II. Some Characteristics of Mammary Tissue Specimens Obtained from Cats

\begin{tabular}{|c|c|c|c|c|c|c|}
\hline Sample & Code & Histology & Cycle & ER & PR & GH mRNA \\
\hline 1 & $\mathrm{~K} 2 \mathrm{R} 1$ & Fibroadenomatous change & MPA $-10 w k$ & 16 & 112 & ++ \\
\hline 2 & KMT56 & Hyperplasia & MPA $-2.5 \mathrm{mo}$ & 55 & 46 & + \\
\hline 3 & GRK28 & Fibroadenoma & $\mathrm{MA}+\mathrm{EE}-1 \mathrm{mo}$ & 6 & 12 & + \\
\hline 4 & GRK40 & Fibroadenomatous change & DA-6 wk & 0 & 67 & + \\
\hline 5 & GRK42 & Fibroadenomatous change & $\mathrm{MA}-1 \mathrm{mo}$ & 15 & 71 & ++ \\
\hline 6 & GRK22 & Epitheliosis & $\mathrm{OVX}-8 \mathrm{mo}$ & 21 & 22 & - \\
\hline 7 & GRK29 & Epitheliosis & $\mathrm{MA}+\mathrm{EE}-5 \mathrm{mo}$ & 13 & 5 & - \\
\hline 8 & GRK33 & Metastasis & OVX $-8 \mathrm{yr}$ & 1 & 3 & - \\
\hline 9 & GRK36 & Carcinoma & $\mathrm{MA}-4 \mathrm{mo}$ & 6 & 4 & - \\
\hline 10 & GRK14 & Carcinoma & MA (continuous) & $<3$ & 16 & + \\
\hline 11 & GRK25 & Carcinoma & $\mathrm{MA}+\mathrm{EE}-3 \mathrm{mo}$ & 41 & 32 & $+1-$ \\
\hline
\end{tabular}

Samples correspond to the numbers of Fig. 5. Code, tissues from female cats except GRK40 = male cat. Cycle, MA, megestrol acetate; EE, ethinyl estradiol; DA, delmadinone acetate; OVX, ovariohysterectomy; the time is the interval between intervention and tissue sampling. ER/PR, receptor concentrations in $\mathrm{fmol} / \mathrm{mg}$ protein in tissue cytosol. GH mRNA, ++, abundant; +, present; -, absent; +/-, faint band.

relation was much less certain for the malignant mammary tumors. It cannot be excluded that in some of the latter tumors GH is produced constitutively even by PR-negative cells. Studies are needed to relate $\mathrm{GH}$ production to steroid receptor concentrations and biologic behavior of the tumor.

The expression of the 600-bp fragment was not related to GH mRNA expression or to histologic criteria of malignancy. The presence of a glycosaminoglycan attachment site and an RGD sequence suggests that this protein belongs to the family of proteoglycans. These proteins are important modifiers of the organization of the pericellular and extracellular matrices. Their functions range from linking proteins to hyaluronan to providing a binding site for fibroblast growth factor or TGF $\beta$ in the extracellular matrix $(36,37)$. The function of this canine protein in cell attachment and/or metastasis needs further characterization.

These data indicate that progestins stimulate benign proliferation of mammary tissue in the dog and the cat by the local induction of the $\mathrm{GH}$ gene. In the dog this results in acromegalic features due to high plasma levels of GH and IGF-I (20). Elevated plasma IGF-I levels may act in concert with the mam-
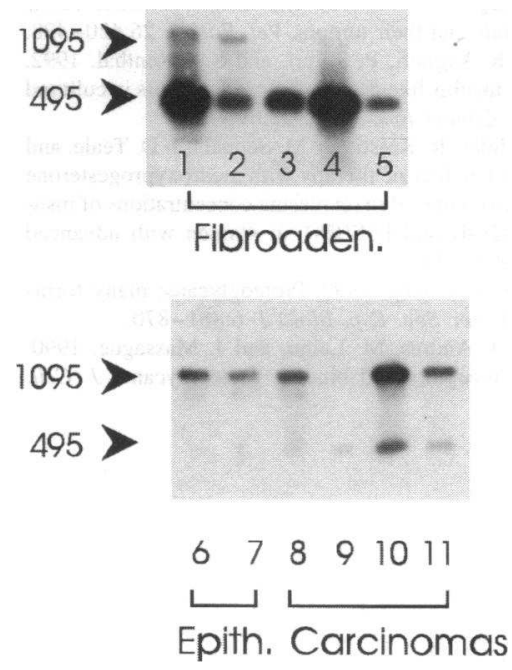

Figure 5. Southern blot hybridization of the RTPCR products obtained from $1 \mu \mathrm{g}$ total RNA of feline mammary tissues hybridized with a ${ }^{32} \mathrm{P}$-labeled canine GH cDNA probe. The codes correspond to the data in Table II. Samples 1-5 are mammary RNA from cats with progestin-induced fibroadenomatous (Fibroaden.) changes. Samples 6 and 7 were obtained from cats with mammary epitheliosis (Epith.), while samples 8-11 were from malignant mammary carcinomas.
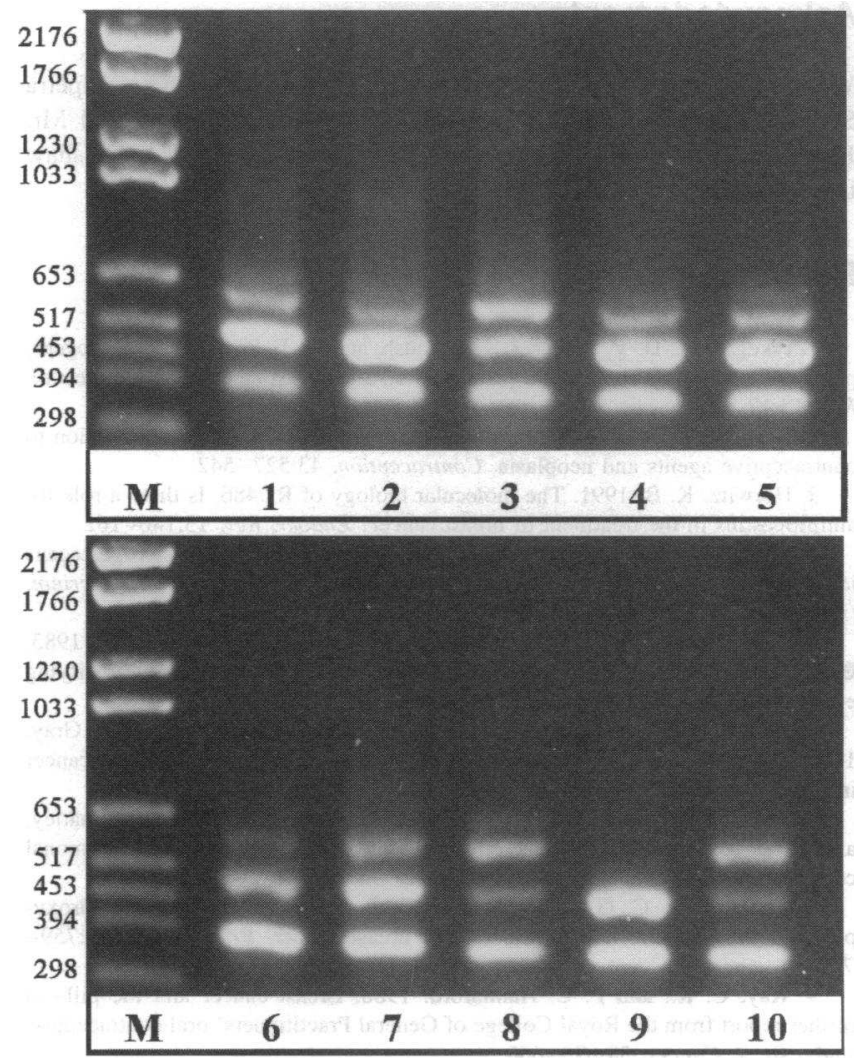

Figure 6. Size separation by electrophoresis on $1.5 \%$ agarose of RTPCR products obtained from $1 \mu \mathrm{g}$ total RNA of normal canine mammary tissue using porcine specific GH primers and human specific $\beta$-actin primers. After electrophoresis the gel was stained with ethidium bromide and photographed under ultraviolet illumination. The lower 383-bp band corresponds to $\beta$-actin. The band at $495 \mathrm{bp}$ is obtained from GH mRNA while a 600 -bp fragment is amplified of unknown origin. Normal mammary tissues were analyzed of dogs treated with progestins (top) or mammary tissue from control dogs (bottom). Sample 9 corresponds to the tissue sample with code P221L5 (Table I), which is normal mammary tissue of a dog treated with proligestone $1 \mathrm{wk}$ before surgical removal of a malignant mammary carcinoma. 


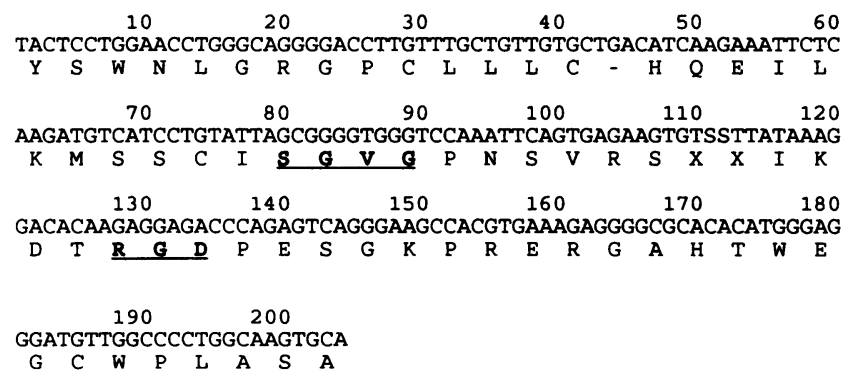

Figure 7. 5'-Nucleotide sequence of the 600-bp fragment amplified by RT-PCR from canine mammary gland RNA using porcine specific GH primers and the translation into protein. There was no homology between this fragment and DNA and protein sequences in the EMBL sequence data bank. An RGD and a glysaminoglycan attachment site $(S G \times G)$ are given in bold.

mary GH to create a highly proliferative environment of the mammary epithelium. The GH mRNA is also found in malignant canine mammary tumors, irrespective of the presence of progesterone receptors.

\section{Acknowledgments}

We gratefully acknowledge the technical assistance of Mrs. Elpetra Sprang, Mrs. Monique van Wolferen, Mrs. Marijke Kwant, and Mr. Joop Fama. The critical reading of the manuscript by Dr. B. E. Belshaw is highly appreciated.

\section{References}

1. Pike, M. C., D. V. Spicer, L. Dahmoush, and M. F. Press. 1993. Estrogens, progestogens, normal breast cell proliferation, and breast cancer risk. Epidemiol. Rev. 15:17-35.

2. King, R. J. B. 1991. Biology of female sex hormone action in relation to contraceptive agents and neoplasia. Contraception. 43:527-542.

3. Horwitz, K. B. 1991. The molecular biology of RU486. Is there a role for antiprogestins in the treatment of breast cancer? Endocr. Rev. 13:146-162.

4. van Leeuwen, F. E. 1991. Epidemiologic aspects of exogenous progestagens in relation to their role in pathogenesis of human breast cancer. Acta Endocrinol. (Copenh.). 125(Suppl. 1):13-26.

5. Pike, M. C., B. E. Henderson, M. D. Krailo, A. Duke, and S. Roy. 1983. Breast cancer in young women and use of oral contraceptives: possibly modifying effect of formulation and age at use. Lancet. 2:926-930.

6. Pike, M. C., B. E. Henderson, J. T. Casagrande, I. Rosario, and G. E. Gray 1981. Oral contraceptive use and early abortion as risk factors for breast cancer in young women. Br. J. Cancer. 43:72-76.

7. Lee, N. C., L. Rosero-Bixby, M. W. Oberle, C. Grimaldo, A. S. Whatley, and E. Z. Rovira. 1987. A case-control study of breast cancer and hormonal contraception in Costa Rica. J. Natl. Cancer Inst. 79:1247-1254.

8. Paul, C., D. C. G. Skegg, and G. F. S. Spears. 1989. Depot medroxyprogesterone (Depo-Provera) and risk of breast cancer. Br. Med. J. 299:759762 .

9. Kay, C. R., and P. C. Hannaford. 1988. Breast cancer and the pill-a further report from the Royal College of General Practitioners' oral contraception study. Br. J. Cancer. 58:675-680.

10. Clarke, C. L., and R. L. Sutherland. 1990. Progestin regulation of cellular proliferation. Endocr. Rev. 11:266-301.

11. Rutteman, G. R. 1992. Contraceptive steroids and the mammary gland: Is there a hazard? Insights from animal studies. Breast Cancer Res. Treat. 23:2941.

12. Casey, H. W., R. C. Giles, and R. P. Kwapien. 1979. Mammary neoplasia in animals. Pathologic aspects and the effect of contraceptive steroids. Recent Results Cancer Res. 66:129-160.

13. El Etreby, M. F., and K. J. Gräf. 1979. Effect of contraceptive steroids on mammary gland of female dog and its relevance to human carcinogenicity. Pharmacol. \& Ther. 5:369-402.

14. Owen, L. N., and M. H. Briggs. 1976. Contraceptive steroid toxicology in the beagle dog and its relevance to human carcinogenecity. Current Medical Research and Opinion. 4:309-329.

15. Misdorp, W. 1991. Progestagens and mammary tumours in dogs and cats. Acta Endocrinol. (Copenh.). 125(Suppl. 1):27-31.

16. Concannon, P. W., N. Altszuler, J. Hampshire, W. B. Butler, and W. Hansel. 1980. Growth hormone, prolactin, and cortisol in dogs developing mammary nodules and an acromegalic-like appearance during treatment with medroxyprogesterone acetate. Endocrinology. 106:1173-1177.

17. Rijnberk, A., J. E. Eigenmann, B. E. Belshaw, J. Hampshire, and N. Altszuler. 1980. Acromegaly associated with transient overproduction of growth hormone in a dog. J. Am. Vet. Med. Assoc. 177:534-537.

18. Eigenmann, J. E., and A. Rijnberk. 1981. Influence of medroxyprogesterone acetate (Provera) on plasma growth hormone levels and on carbohydrate metabolism. I. Studies in the ovariohysterectomized bitch. Acta Endocrinol. (Copenh.). 98:599-602.

19. Eigenmann, J. E., R. Y. Eigenmann, A. Rijnberk. I. Van der Gaag, J. Zapf, and E. R. Froesch. 1983. Progesterone-controlled growth hormone overproduction and naturally occurring canine diabetes and acromegaly. Acta Endocrinol. (Copenh.). 104:167-176.

20. Selman, P. J., J. A. Mol, G. R. Rutteman, and A. Rijnberk. 1994. Progestininduced growth hormone excess in the dog originates in the mammary gland. Endocrinology. 134:287-292.

21. Hayden, D. W., K. H. Johnson, and H. K. Ghobrial. 1983. Ultrastructure of feline mammary hypertrophy. Vet. Pathol. 20:254-264.

22. Hayden, D. W., D. M. Barnes, and K. H. Johnson. 1989. Morphologic changes in the mammary gland of megestrol acetate-treated and untreated cats. Vet. Pathol. 26:104-113.

23. Peterson, M. E. 1987. Effects of megestrol acetate on glucose tolerance and growth hormone secretion in the cat. Res. Vet. Sci. 42:354-357.

24. Hampe, J. F., and W. Misdorp. 1979. Tumours and dysplasias of the mammary gland. Bull. WHO. 50:111-113.

25. Mol, J. A., M. M. Kwant, I. C. J. Arnold, and H. A. W. Hazewinkel. 1991. Elucidation of the sequence of canine (pro)-calcitonin. A molecular biological and protein chemical approach. Regul. Pept. 35:189-195.

26. Rutteman, G. R., N. Willekes-Koolschijn, M. M. Bevers, A. A. van der Gugten, and W. Misdorp. 1986. Prolactin binding in benign and malignant mammary tissue of female dogs. Anticancer Res. 6:829-835.

27. Osborne, C. K., and C. L. Arteaga. 1990. Autocrine and paracrine growth regulation of breast cancer: clinical implications. Breast Cancer Res. Treat. 15:311.

28. Fields, K., E. Kulig, and R. V. Lloyd. 1993. Detection of prolactin messenger RNA in mammary and other normal and neoplastic tissues by polymerase chain reaction. Lab. Invest. 68:354-360.

29. Blankenstein, M. A., I. Maitimu-Smeele, G. H. Donker, J. Daroszewski, A. Milewicz, and J. H. Thijssen. 1992. On the significance of in situ production of oestrogens in human breast cancer tissue. J. Steroid Biochem. Mol. Biol. 41:891-896.

30. Feldman, M., W. Ruan, B. C. Cunningham, J. A. Wells, and D. L. Kleinberg. 1993. Evidence that the growth hormone receptor mediates differentiation and development of the mammary gland. Endocrinology. 133:1602-1608.

31. Green, H., M. Morikawa, and T. Nixon. 1985. A dual effector theory of growth-hormone action. Differentiation. 29:195-198.

32. Lead article. 1989. Stem cells in neoplasia. Lancet. 1:701-702.

33. Hellmen, E., and A. Lindgren. 1989. The expression of intermediate filaments in canine mammary glands and their tumors. Vet. Pathol. 26:420-428.

34. Goldfine, I. D., V. Papa, R. Vigneri, P. Siiteri, and S. Rosenthal. 1992. Progestin regulation of insulin and insulin-like growth factor I receptors in cultured human breast cancer cells. Breast Cancer Res. Treat. 22:69-79.

35. Reed, M. J., A. Christodoulides, R. Koistinen, M. Seppälä, J. D. Teale, and M. W. Ghilchik. 1992. The effect of endocrine therapy with medroxyprogesterone acetate, 4-hydroxyandrostenedione or tamoxifen on plasma concentrations of insulin-like growth factor (IGF)-I, IGF-II and IGFBP-1 in women with advanced breast cancer. Int. J. Cancer. 52:208-212.

36. Hardingham, T. E., and A. J. Fosang. 1992. Proteoglycans: many forms and many functions. FASEB (Fed. Am. Soc. Exp. Biol.) J. 6:861-870.

37. Boyd, F. T., S. Cheifetz, J. Andres, M. Laiho, and J. Massague. 1990. Transforming growth factor-beta receptors and binding proteoglycans. J. Cell. Sci. Suppl. 13:131-138. 